\title{
Large-cell neuroendocrine carcinoma of lung with epidermal growth factor receptor (EGFR) gene mutation and co-expression of adenocarcinoma markers: a case report and review of the literature
}

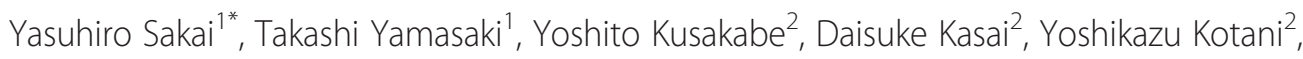
Yoshihiro Nishimura ${ }^{2}$ and Tomoo Itoh $^{1}$

\begin{abstract}
Purpose: A high rate of response to treatment with epidermal growth factor receptor tyrosine kinase inhibitor (EGFR-TKI) has been observed in certain patients (women, of East Asian ethnicity, with non-smoking history and adenocarcinoma histology) with mutations in exons 18 to 21 of the tyrosine kinase domain of EGFR. Some cases of high-grade neuroendocrine carcinoma of the lung harboring mutations have been sporadically reported.

Methods: We describe the case of a 78-year-old woman with large-cell neuroendocrine carcinoma of the lung, with mutation in exon 21 L858R and co-expression of adenocarcinoma markers.

Results: A mass (3.0 cm in diameter) was identified in the inferior lobe of the left lung, accompanied by metastases into ipsilateral mediastinal lymph nodes and elevations of serum pro-gastrin-releasing peptide and carcinoembryonic antigen. Initial transbronchial brushing cytology suggested high-grade neuroendocrine carcinoma favoring small-cell carcinoma in poorly smeared and degenerated preparations, and revealed exon 21 L858R mutation. Re-enlargement of the cancer and bone metastases was observed after chemotherapy, and further testing suggested large-cell neuroendocrine carcinoma with immunoreactivity to markers of primary lung adenocarcinoma and L858R mutation. High-grade neuroendocrine carcinoma with mutations in the tyrosine kinase domain of EGFR may be associated with adenocarcinoma, as reviewed from the literature and may also apply to our case.
\end{abstract}

Conclusions: EGFR-TKI could provide better quality of life and survival in patients with advanced or relapsed high-grade neuroendocrine carcinoma with EGFR gene mutations. Further studies in this respect are warranted.

Keywords: Epidermal growth factor receptor, Gene mutation, Large-cell neuroendocrine carcinoma, Lung cancer, Small-cell carcinoma, Tyrosine kinase inhibitor

\section{Background}

The entry of tyrosine kinase inhibitors (TKIs) gefitinib (Iressa ${ }^{\circ}$, AstraZeneca, Wilmington, Delaware) and erlotinib (Tarceva ${ }^{\circ}$, Genentech, South San Francisco, California), which target epidermal growth factor receptor (EGFR), is one of the most recent, gratifying events in the treatment of advanced non-small-cell lung cancer (NSCLC). Clinical trials have revealed significant variability in response to

\footnotetext{
* Correspondence: sakaiyasuhiro@gaia.eonet.ne.jp

1 Department of Diagnostic Pathology, Kobe University Hospital, 7-5-2

Kusunoki-cho, Chuo-ku, Kobe-shi, Hyogo 650-0017, Japan

Full list of author information is available at the end of the article
}

EGFR-TKIs, and patient characteristics such as sex, dominantly female, East Asian ethnicity, non-smoking history, and adenocarcinoma (ADC) histology have been associated with an increased likelihood of EGFR-TKI effectiveness [1-7]. Furthermore, a high response rate (60 to $90 \%)$ to treatment with EGFR-TKIs has been observed in patients harboring mutations in exons 18 to 21 of the tyrosine kinase domain of EGFR, with exon 19 deletions and exon 21 L858R point mutations comprising about $90 \%$ of all mutations $[8,9]$. Although the mechanism of lethal interstitial pneumonia as a side effect of EGFR-TKI is still unknown, EGFR-TKI can be striking 
in cancer reduction and quality of life improvement in patients with advanced NSCLC harboring EGFR gene mutations. Currently, EGFR-TKI is considered third-line chemotherapy for patients with inoperable and recurrent NSCLC after first-line platinum-based combination chemotherapy and second-line chemotherapy with docetaxel; however, in future the combination of cytotoxic agents and EGFR-TKI may become first- or second-line standard chemotherapy. According to the statement of the International Association for the Study of Lung Cancer/American Thoracic Society/European Respiratory Society about lung ADC [10], EGFR gene mutation should be routinely examined in all patients with NSCLC before nonsurgical treatment and after the initiation of EGFR-TKI therapy, with a view of predicting reactivity and resistance to EGFR-TKI, if possible, with the use of Kirsten rat sarcoma virus oncogene homolog (KRAS) mutation and anaplastic lymphoma kinase (ALK) rearrangement [11-16].

Interestingly, case reports of small-cell lung carcinoma (SCLC) harboring EGFR gene mutation and apparently responding to EGFR-TKI have sporadically appeared since 2005 [17-27]. The mechanism by which SCLC acquires EGFR gene mutation is still unknown, but such cases may occur in association with ADC. Moreover, a few cases of large-cell neuroendocrine carcinoma (LCNEC) with EGFR gene mutations have recently been identified [28-30], an additional case of which is described here.

\section{Case presentation}

A 78-year-old Japanese woman ex-smoker (half a pack per day) with past histories of pulmonary tuberculosis and uterine leiomyoma had been under medical treatment for chronic heart failure with atrial fibrillation, unstable angina, eosinophilic myocarditis, bronchial asthma, hyperuricemia, hyperlipidemia, and hypothyroidism. At a follow-up examination one and half year earlier, chest computed tomography showed a mass $(1.5 \mathrm{~cm}$ in diameter) in the inferior lobe of the left lung. It had doubled in size within the following four months, and positron emission tomography (PET) and magnetic resonance imaging (MRI) revealed metastases to ipsilateral mediastinal lymph nodes. Serum tumor markers were as follows: pro-gastrin-releasing peptide $105 \mathrm{pg} / \mathrm{ml}$ (standard range 0 - 80), carcinoembryonic antigen (CEA) $21.8 \mathrm{ng} / \mathrm{ml}$ $(0-5.2)$, and cytokeratin 19 fragment $3.0 \mathrm{ng} / \mathrm{ml}(0-2)$. Transbronchial brushing and needle aspiration against the tumor demonstrated small cells with a high nuclear/ cytoplasm ratio and fine granular nuclear chromatin scattered around a large cell cluster in poorly smeared Papanicolaou stains, suggesting high-grade neuroendocrine carcinoma favoring small-cell carcinoma (Figure 1, upper panels). EGFR L858R mutation was detected in exon 21 (PNA LNA PCR-Clamp method) of another brushing and aspiration specimen. The patient received four cycles of systemic chemotherapy with carboplatin (area under curve 5) and etoposide $\left(80 \mathrm{mg} / \mathrm{m}^{2}\right)$ for three months, at the end of which the size of the tumor decreased by one half. Lumbago developed after six months, and metastases to the left iliac bone and the femur were detected by MRI. Focal radiotherapy (39Gy/13Fr) was carried out. The primary lesion had doubled again during the following four months with enlargement of mediastinal lymph nodes. Histopathologic and cytologic follow up examinations were carried out: Papanicolaou smears revealed cells larger than those at previous examinations, and numerous scattered sheet-like arrangements. The cells had fine granular nuclear chromatin and prominent large nucleoli of a high nuclear/cytoplasm ratio and relatively rich cytoplasm (Figure 1, lower panels). Transbronchial lung biopsy failed to provide detailed histology of the tumor cells because of insufficient sampling volume, and proliferative patterns such as organoid structures and nuclear molding could not be identified. Immunohistochemical analysis showed tumor cell immunoreactivity to three neuroendocrine markers: chromogranin A, synaptophysin, and CD56 (Figure 2). Retrospectively, the cells subject of the second examination showed almost the same morphology as that of cells of the first test regardless of artifactual degeneration. Consequently, the tumor was diagnosed as large-cell neuroendocrine carcinoma. Thyroid transcription factor- 1 was diffusely and strongly positive in the cells. Interestingly, CEA and Napsin A were also focally positive. It is noteworthy that the mutationspecific immunostaining for the detection of EGFR exon 21 L858R mutation (rabbit monoclonal antibody, 1:100, clone 43B2, Cell Signaling Technology ${ }^{\circ}$, Danvers, MA) was positive (Figure 2). Second-line chemotherapy is under consideration at present.

\section{Discussion}

With the present case we aim to demonstrate a possible additional case of LCNEC with EGFR gene mutation. Three other cases have been reported retrospectively (Table 1), and although no clinicopathologic feature has been identified in them, two have occurred in nonsmokers, two show EGFR gene exon 19 deletion mutation, and one demonstrates exon 18 point mutation [28-30]. Ours may be the first in an ex-smoker with LCNEC harboring exon 21 L858R point mutation. The mechanism and significance of EGFR gene mutation in LCNEC is still unknown. Nonetheless, twenty cases of SCLC with EGFR gene mutation have been reported and are used in this discussion (Table 1) [18-27]. Among these SCLC cases, the ratio of male: female is 1:3 (age $60.9 \pm 26.1$ years; range, $36-89$ ), and of smoker: non- 


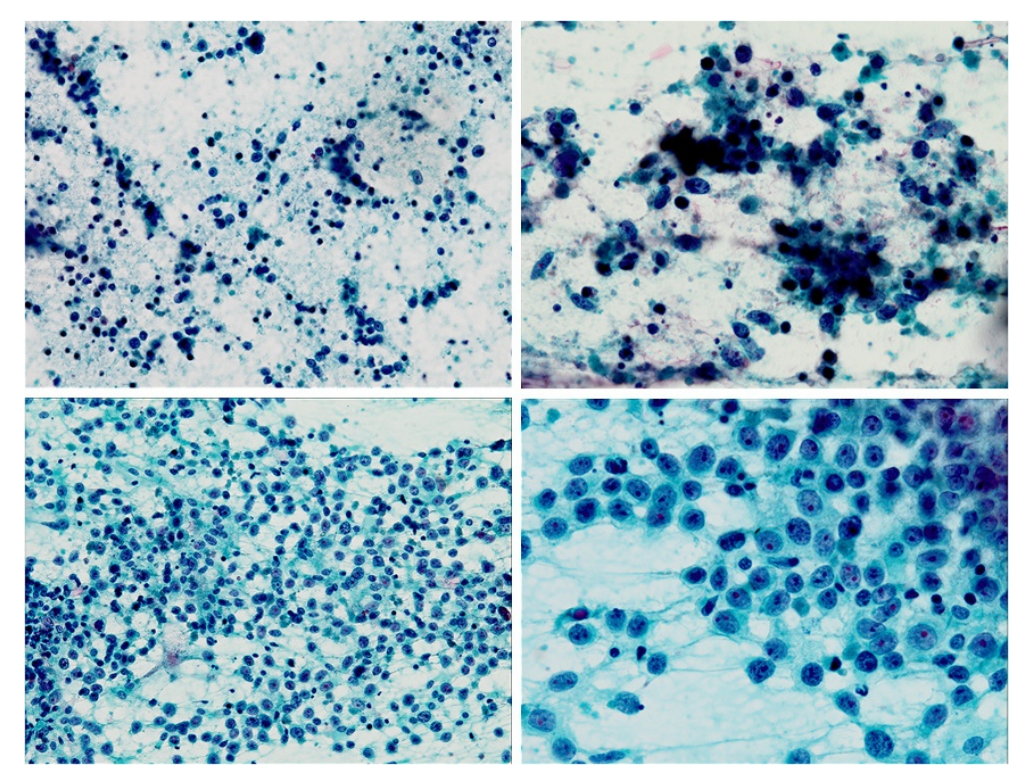

Figure 1 Papanicolaou smears from the first examination diagnosed as high-grade neuroendocrine carcinoma favoring small-cell carcinoma (upper panels left to right: $\times 200, \times 400$ ), and the second examination diagnosed as large-cell neuroendocrine carcinoma (lower panels: $\times 200, \times 400$ ).

smoker 2:3. Strikingly, fourteen (70\%) show combined SCLC and adenocarcinoma, or suggest a transformation from adenocarcinoma to SCLC; eleven display EGFR gene exon 19 deletion mutation, and eight exon 21 L858R point mutation proportionally similar to mutations in adenocarcinoma. Whether LCNEC with EGFR gene mutation is related to adenocarcinoma is still unknown, although only one case has suggested transformation from adenocarcinoma to LCNEC [30]. The present case was, however, immunoreactive to adenocarcinoma markers
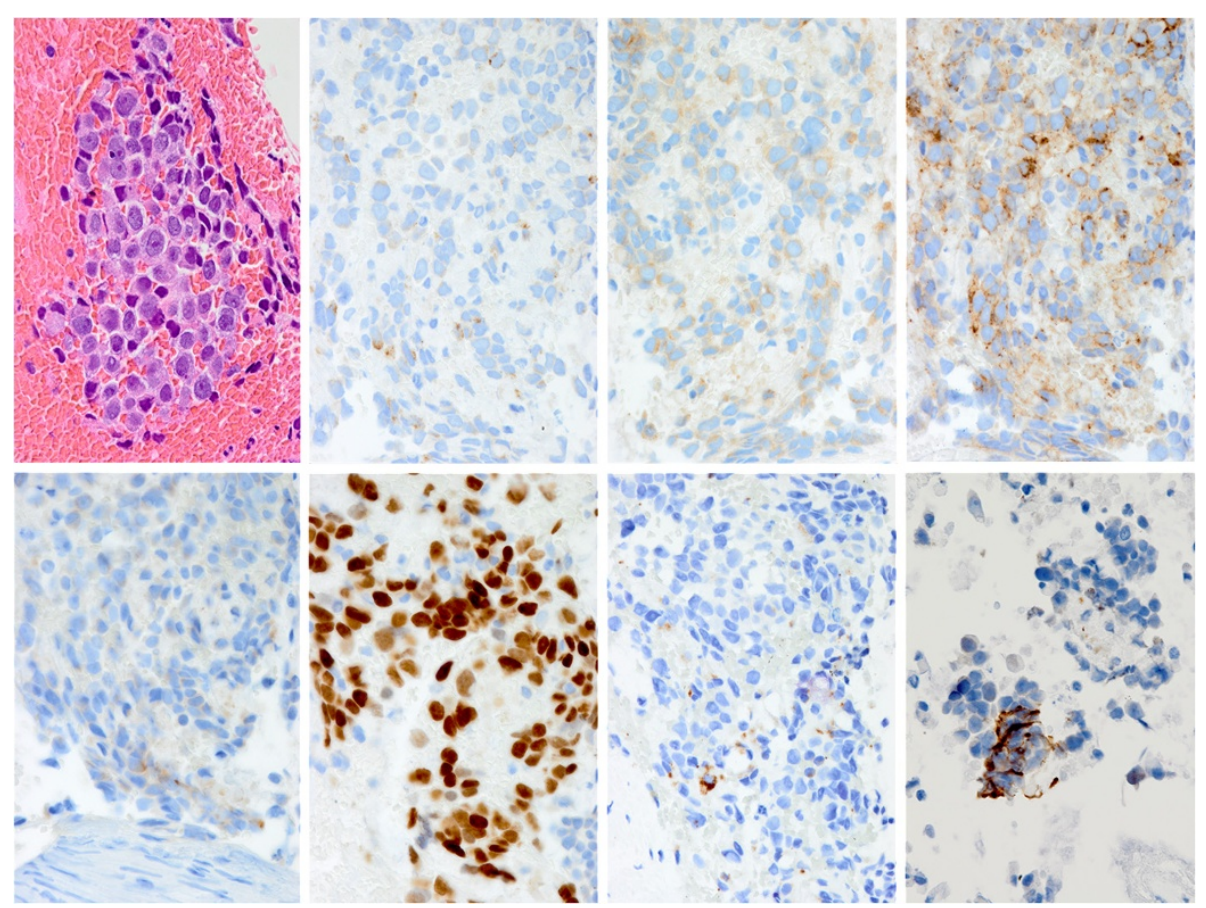

Figure 2 Histopathologic stains from the second transbronchial biopsy. Upper panels left to right: hematoxylin and eosin, chromogranin A, synaptophysin, CD56; lower panels: carcinoembryonic antigen, thyroid transcription factor-1, Napsin A, epidermal growth factor receptor L858R mutation $(\times 400)$. 
Table 1 Review of epidermal growth factor receptor gene mutation in patients with high-grade neuroendocrine carcinoma and its combination with other types

\begin{tabular}{|c|c|c|c|c|c|c|c|}
\hline Authors & Age & Gender & Smoking & Stage & Cell type & Specimen & Activating EGFR mutation \\
\hline Okamoto et al. (2006) & 72 & $\mathrm{~F}$ & No & IV & $\mathrm{SCLC}$ & biopsy & exon 19, del E746-A750 \\
\hline Zakowski et al. (2006) & 45 & $\mathrm{~F}$ & No & IV & $\mathrm{ADC} \rightarrow \mathrm{SCLC}$ & biopsy & exon 19, del L747-P753insQ \\
\hline Morinaga et al. (2007) & 46 & $\mathrm{~F}$ & No & $\| I B$ & $\mathrm{ADC} \rightarrow \mathrm{SCLC}$ & biopsy & exon 19, del E746-A750 \\
\hline Fukui et al. (2007) & 62 & $\mathrm{~F}$ & No & $\| I \mathrm{~B}$ & combined SCLC and ADC & resection & exon 21, L858R mutaion \\
\hline \multirow[t]{5}{*}{ Tatematsu et al. (2008) } & 36 & $\mathrm{~F}$ & No & IV & combined SCLC and ADC & resection & exon 21, L858R mutaion \\
\hline & 81 & M & Yes & IV & $\mathrm{SCLC}$ & biopsy & exon $18, \mathrm{G} 719 \mathrm{~A}$ point mutation \\
\hline & 69 & M & Yes & $\mathrm{IA}$ & combined SCLC and ADC & biopsy & exon 21, L858R mutaion \\
\hline & 89 & $\mathrm{~F}$ & Yes & IB & $\mathrm{SCLC}$ & biopsy & exon 21, L858R mutaion \\
\hline & 65 & M & Yes & $\| \mathrm{A}$ & combined SCLC and ADC & resection & exon 19, 15-bp deletion \\
\hline Alam et al. (2010) & 73 & $\mathrm{~F}$ & No & IV & ADC (lung), SCLC (liver) & biopsy & exon 21, L858R mutaion \\
\hline \multirow[t]{2}{*}{ Shiao et al. (2011) } & 63 & M & Yes & III & SCLC & biopsy & exon 19 deletion (del E746-S752 insV) \\
\hline & 54 & $\mathrm{~F}$ & No & $\|-\| \mid$ & $\mathrm{SCLC}$ & biopsy & exon 19 deletion (del E746-A750) \\
\hline \multirow[t]{5}{*}{ Sequist et al. (2011) } & 67 & $\mathrm{~F}$ & NA & NA & $\mathrm{ADC} \rightarrow \mathrm{SCLC}$ & biopsy & exon 21, L858R mutaion \\
\hline & 54 & $\mathrm{~F}$ & NA & NA & $\mathrm{ADC} \rightarrow \mathrm{SCLC}$ & biopsy & exon 19 deletion \\
\hline & 56 & $\mathrm{~F}$ & NA & IV & $\mathrm{ADC} \rightarrow \mathrm{SCLC}$ & biopsy & exon 21, L858R mutaion \\
\hline & 40 & $\mathrm{~F}$ & NA & NA & $\mathrm{ADC} \rightarrow \mathrm{SCLC}$ & biopsy & exon 19 deletion \\
\hline & 61 & $\mathrm{~F}$ & NA & NA & $\mathrm{ADC} \rightarrow \mathrm{SCLC}$ & biopsy & exon 21, L858R mutaion \\
\hline lyoda et al. (2011) & NA & NA & NA & NA & LCNEC & resection & exon 18 , codon 725 (ACG to ACA) \\
\hline De Pas et al. (2011) & 66 & M & No & IV & LCNEC & biopsy & exon 19 deletion (p.L747_A755>AT) \\
\hline Yanagisawa et al. (2012) & 46 & M & No & IIIA & $\mathrm{ADC} \rightarrow \mathrm{LCNEC}$ & resection $\rightarrow$ biopsy & exon 19 micro-deletion \\
\hline \multirow[t]{2}{*}{ Lu et al. (2012) } & 61 & M & Yes & $\| \mathrm{A}$ & combined SCLC and SQCC & resection & exon 19, del E746-A750 (K745 AAA) \\
\hline & 62 & $\mathrm{~F}$ & No & $\| I A$ & combined SCLC and ADC & resection & exon 19, del E746-A750 (K745 AAA) \\
\hline Lu et al. (2012) & 62 & $\mathrm{~F}$ & No & IIIA & combined SCLC and ADC & resection & exon 19 mutation, codon 746-754 \\
\hline Our case (2012) & 78 & $\mathrm{~F}$ & Yes (Ex) & IV & LCNEC & brushing & exon 21, L858R mutaion \\
\hline
\end{tabular}

ADC, adenocarcinoma; EGFR, epidermal growth factor receptor, F, female; LCNEC, large-cell neuroendocrine carcinoma; M, male; NA, not available; SCLC, small-cell lung cancer; SQCC, squamous cell carcinoma.

TTF-1, Napsin A, and CEA, not to entrapped non-tumor alveolar cells, which was a conspicuous finding when considering the occurrence of LCNEC with EGFR gene mutation.

Distinctly, the detection of EGFR exon 21 L858R mutation by PCR on the first specimen might have been due to the very few adenocarcinoma cells, combined type with adenocarcinoma. Adenocarcinoma might have been present before the development of LCNEC and before the first biopsy. It can be assumed that the present case was consistently adenocarcinoma with neuroendocrine differentiation harboring EGFR exon 21 L858R mutation. Neuroendocrine proliferative patterns, such as organoid ones and nuclear molding, were not identified in the whole section of the surgical specimen. Also, the clonal relation between the first and second tests was not clear because the mutational status of the EGFR gene in the second biopsy was not addressed by PCR. Nonetheless, this case might be consistently LCNEC harboring EGFR exon 21 L858R mutation, especially that the cytologic features displayed by both tests were almost the same, noting specially the PCR conducted on the same tumor cells as those of the Papanicolaou preparations, and the positivity of EGFR exon 21 L858R mutation-specific immunostaining in the second biopsy. Indeed, high-grade neuroendocrine carcinoma harboring EGFR gene mutation may have molecular adenocarcinomatous characteristics, at least by derivation from the literature about cases like the present one. Further studies are needed on the occurrence of high-grade neuroendocrine carcinoma harboring EGFR gene mutation.

An additional therapeutic choice for high-grade neuroendocrine carcinoma showing poor prognosis is expected, and EGFR-TKI that is now available commercially should naturally be considered even for this carcinoma, much more than for one with adenocarcinomatous characteristics. Presently there is no regimen of chemotherapy for high-grade neuroendocrine carcinoma harboring EGFR gene mutation. Nonetheless, the detection of this disease needs to be attempted through further study. The 
prerequisite to administering EGFR-TKI for NSCLC is the presence of EGFR gene mutation, as opposed to resistance mutation such as that of exon 20 T790M, exon 19 D761Y, and exon 21T854A $[11,31,32]$. Testing for the presence of EGFR gene mutation by PCR in SCLC and LCNEC may, however, be practically difficult from the aspect of cost and rarity. Immunohistochemistry may be one of the strategies for easy detection of EGFR gene mutation. Available and noteworthy are two mutation-specific antibodies for the detection of EGFR gene mutations: anti-EGFR exon 19 E746-750 deletion antibody (rabbit monoclonal, clone 6B6, Cell Signaling Technology", Danvers, MA) along with anti-EGFR exon 21 L858R mutation antibody [33,34]. Anti-EGFR exon 21 L858R mutation-specific immunostaining of lung adenocarcinoma demonstrates excellent sensitivity $(95.2 \%)$ and specificity (98.8\%), although the former may react to exon 19 deletion overlapping E746-A750. Immunostaining with these antibodies is less costly and easier to conduct than by molecular detection of EGFR gene mutation, covers the two major patterns of EGFR gene mutation, and can be used for SCLC and LCNEC in which EGFR gene mutation is less frequent than in ADC.

\section{Conclusions}

The fact that patients with lung cancer have as many therapeutic choices as possible is gratifying. High-grade neuroendocrine carcinoma generally shows more aggressiveness and rapid relapse than NSCLC. Interestingly, our case suggests the presence of high-grade neuroendocrine carcinoma harboring EGFR gene mutation: EGFR-TKI may provide better quality of life and survival in patients with advanced or relapsed high-grade neuroendocrine carcinoma, particularly that with EGFR gene mutation. EGFR gene mutation-specific immunostaining is potentially effective and should be utilized for easy detection and further study of this rare disease.

\section{Consent}

Written informed consent was obtained from the patient for publication of this case report and any accompanying images. A copy of the written consent is available for review by the Editor-in-Chief of this journal.

\section{Competing interests}

The authors have no grant for this research and no competing interest to declare.

\section{Authors' contributions}

All authors read and approved the final manuscript.

\section{Acknowledgements}

This case has been reported in cooperation with Dr. Shuntaro Tokunaga, Dr. Yukihisa Hatakeyama, Dr. Yoshitaka Kawa, Dr. Daisuke Tamura, Dr. Suya Hori, Dr. Haruko Shinke, Dr. Tomomi Kawaguchi, Dr. Yumiko Ishikawa, Dr. Nobuko Hazeki, Dr. Tatsuya Nagano, Dr. MotokoTachihara, Dr. Akihiro Sakashita, Dr. Kazuyuki Kobayashi, Dr. Yasuhiro Funada (Department of Respiratory
Medicine, Kobe University Hospital); Dr. Daisuke Hokka, Dr. Shinya Tane, Dr. Shunsuke Tauchi, Dr. Yoshimasa Maniwa (Department of Thoracic Surgery, Kobe University Hospital); Dr. Mizuho Nishio, Dr. Hisanobu Koyama, Dr. Hideki Nishimura, Dr. Ryoji Ohno (Department of Radiology, Kobe University Hospital).

\section{Author details}

1Department of Diagnostic Pathology, Kobe University Hospital, 7-5-2 Kusunoki-cho, Chuo-ku, Kobe-shi, Hyogo 650-0017, Japan. ${ }^{2}$ Department of Respiratory Medicine, Kobe University Hospital, 7-5-2 Kusunoki-cho, Chuo-ku, Kobe-shi, Hyogo 650-0017, Japan.

Received: 5 February 2013 Accepted: 31 May 2013

Published: 18 July 2013

\section{References}

1. Bell DW, Lynch TJ, Haserlat SM, Harris PL, Okimoto RA, Brannigan BW, Sgroi DC, Muir B, Riemenschneider MJ, lacona RB, Krebs AD, Johnson DH, Giaccone G, Herbst RS, Manegold C, Fukuoka M, Kris MG, Baselga J, Ochs JS, Haber DA: Epidermal growth factor receptor mutations and gene amplification in non-small-cell lung cancer: molecular analysis of the IDEAL/INTACT gefitinib trials. J Clin Oncol 2005, 23:8081-8092.

2. Douillard JY, Shepherd FA, Hirsh V, Mok T, Socinski MA, Gervais R, Liao ML, Bischoff H, Reck M, Sellers MV, Watkins CL, Speake G, Armour AA, Kim ES: Molecular predictors of outcome with gefitinib and docetaxel in previously treated non-small-cell lung cancer: data from the randomized phase III INTEREST trial. J Clin Oncol 2010, 28:744-752.

3. Eberhard DA, Johnson BE, Amler LC, Goddard AD, Heldens SL, Herbst RS, Ince WL, Jänne PA, Januario T, Johnson DH, Klein P, Miller VA, Ostland MA, Ramies DA, Sebisanovic D, Stinson JA, Zhang YR, Seshagiri S, Hillan KJ: Mutations in the epidermal growth factor receptor and in KRAS are predictive and prognostic indicators in patients with non-small-cell lung cancer treated with chemotherapy alone and in combination with erlotinib. J Clin Oncol 2005, 23:5900-5909.

4. Hirsch FR, Varella-Garcia M, Bunn PA Jr, Franklin WA, Dziadziuszko R, Thatcher N, Chang A, Parikh P, Pereira JR, Ciuleanu T, Von Pawel J, Watkins C, Flannery A, Ellison G, Donald E, Knight L, Parums D, Botwood N, Holloway B: Molecular predictors of outcome with gefitinib in a phase III placebocontrolled study in advanced non-small-cell lung cancer. J Clin Oncol 2006, 24:5034-5042

5. Wheatley-Price P, Ding K, Seymour L, Clark GM, Shepherd FA: Erlotinib for advanced non-small-cell lung cancer in the elderly: an analysis of the National Cancer Institute of Canada Clinical Trials Group Study BR.21. J Clin Oncol 2008, 26:2350-2357.

6. Pao W, Miller V, Zakowski M, Doherty J, Politi K, Sarkaria I, Singh B, Heelan R, Rusch V, Fulton L, Mardis E, Kupfer D, Wilson R, Kris M, Varmus H: EGF receptor gene mutations are common in lung cancers from "never smokers" and are associated with sensitivity of tumors to gefitinib and erlotinib. Proc Natl Acad Sci USA 2004, 101:13306-13311.

7. Mitsudomi T, Kosaka T, Endoh H, Horio Y, Hida T, Mori S, Hatooka S, Shinoda M, Takahashi T, Yatabe Y: Mutations of the epidermal growth factor receptor gene predict prolonged survival after gefitinib treatment in patients with non-small-cell lung cancer with postoperative recurrence. J Clin Oncol 2005, 23:2513-2520.

8. Lynch TJ, Bell DW, Sordella R, Gurubhagavatula S, Okimoto RA, Brannigan BW, Harris PL, Haserlat SM, Supko JG, Haluska FG, Louis DN, Christiani DC, Settleman J, Haber DA: Activating mutations in the epidermal growth factor receptor underlying responsiveness of non-small-cell lung cancer to gefitinib. N Engl J Med 2004, 350:2129-2139.

9. Paez JG, Jänne PA, Lee JC, Tracy S, Greulich H, Gabriel S, Herman P, Kaye FJ, Lindeman N, Boggon TJ, Naoki K, Sasaki H, Fujii Y, Eck MJ, Sellers WR, Johnson BE, Meyerson M: EGFR mutations in lung cancer: correlation with clinical response to gefitinib therapy. Science 2004, 304:1497-1500.

10. Travis WD, Brambilla E, Noguchi M, Nicholson AG, Geisinger KR, Yatabe $Y$, Beer DG, Powell CA, Riely GJ, Van Schil PE, Garg K, Austin JH, Asamura H, Rusch WW, Hirsch FR, Scagliotti G, Mitsudomi T, Huber RM, Ishikawa Y, Jett J, Sanchez-Cespedes M, Sculier JP, Takahashi T, Tsuboi M, Vansteenkiste J, Wistuba I, Yang PC, Aberle D, Brambilla C, Flieder D, Franklin W, Gazdar A, Gould M, Hasleton P, Henderson D, Johnson B, Johnson D, Kerr K, Kuriyama K, Lee JS, Miller VA, Petersen I, Roggli V, Rosell R, Saijo N, Thunnissen E, Tsao M, Yankelewitz D: International association for the study of lung cancer/ 
american thoracic society/european respiratory society international multidisciplinary classification of lung adenocarcinoma. J Thorac Oncol 2011, 6:244-285

11. Pao W, Miller VA, Politi KA, Riely GJ, Somwar R, Zakowski MF, Kris MG, Varmus $\mathrm{H}$ : Acquired resistance of lung adenocarcinomas to gefitinib or erlotinib is associated with a second mutation in the EGFR kinase domain. PLoS Med 2005, 2:e73.

12. Zhu CQ, Da Cunha Santos G, Ding K, Sakurada A, Cutz JC, Liu N, Zhang T, Marrano P, Whitehead M, Squire JA, Kamel-Reid S, Seymour L, Shepherd FA, Tsao MS, National Cancer Institute of Canada Clinical Trials Group Study BR.21: Role of KRAS and EGFR as biomarkers of response to erlotinib in National Cancer Institute of Canada Clinical Trials Group Study BR.21. J Clin Oncol 2008, 26:4268-4275.

13. Mao C, Qiu LX, Liao RY, Du FB, Ding H, Yang WC, Li J, Chen Q: KRAS mutations and resistance to EGFR-TKIs treatment in patients with nonsmall cell lung cancer: a meta-analysis of 22 studies. Lung Cancer 2010, 69:272-278.

14. Cadranel J, Mauguen A, Faller M, Zalcman G, Buisine MP, Westeel V, Longchampt E, Wislez M, Coudert B, Daniel C, Chetaille B, Michiels S, Blons H, Solassol J, De Fraipont F, Foucher P, Urban T, Lacroix L, Poulot V, Quoix E, Antoine M, Danton G, Morin F, Chouaid C, Pignon JP: Impact of systematic EGFR and KRAS mutation evaluation on progression-free survival and overall survival in patients with advanced non-small-cell lung cancer treated by erlotinib in a French prospective cohort (ERMETIC projectpart 2). J Thorac Oncol 2012, 7:1490-1502.

15. Boland JM, Erdogan S, Vasmatzis G, Yang P, Tillmans LS, Johnson MR, Wang $X$, Peterson LM, Halling KC, Oliveira AM, Aubry MC, Yi ES: Anaplastic lymphoma kinase immunoreactivity correlates with ALK gene rearrangement and transcriptional up-regulation in non-small cell lung carcinomas. Hum Pathol 2009, 40:1152-1158.

16. Yi ES, Boland JM, Maleszewski JJ, Roden AC, Oliveira AM, Aubry MC, Erickson-Johnson MR, Caron BL, Li Y, Tang H, Stoddard S, Wampfler J, Kulig $\mathrm{K}$, Yang P: Correlation of IHC and FISH for ALK gene rearrangement in non-small cell lung carcinoma: IHC score algorithm for FISH. J Thorac Oncol 2011, 6:459-465

17. Araki J, Okamoto I, Suto R, Ichikawa Y, Sasaki J: Efficacy of the tyrosine kinase inhibitor gefitinib in a patient with metastatic small cell lung cancer. Lung Cancer 2005, 48:141-144.

18. Okamoto I, Araki J, Suto R, Shimada M, Nakagawa K, Fukuoka M: EGFR mutation in gefitinib-responsive small-cell lung cancer. Ann Oncol 2006, 17:1028-1029.

19. Zakowski MF, Ladanyi M, Kris MG, Memorial Sloan-Kettering Cancer Center Lung Cancer OncoGenome Group: EGFR mutations in small-cell lung cancers in patients who have never smoked. N Engl J Med 2006 355:213-215.

20. Morinaga R, Okamoto I, Furuta K, Kawano Y, Sekijima M, Dote K, Satou T, Nishio K, Fukuoka M, Nakagawa K: Sequential occurrence of non-small cell and small cell lung cancer with the same EGFR mutation. Lung Cancer 2007, 58:411-413.

21. Fukui $T$, Tsuta $K$, Furuta $K$, Watanabe $S$, Asamura $H$, Ohe $Y$, Maeshima AM, Shibata T, Masuda N, Matsuno Y: Epidermal growth factor receptor mutation status and clinicopathological features of combined small cell carcinoma with adenocarcinoma of the lung. Cancer Sci 2007, 98:1714-1719.

22. Tatematsu A, Shimizu J, Murakami Y, Horio Y, Nakamura S, Hida T, Mitsudomi T, Yatabe Y: Epidermal growth factor receptor mutations in small cell lung cancer. Clin Cancer Res 2008, 14:6092-6096.

23. Alam N, Gustafson KS, Ladanyi M, Zakowski MF, Kapoor A, Truskinovsky AM, Dudek AZ: Small-cell carcinoma with an epidermal growth factor receptor mutation in a never-smoker with gefitinib-responsive adenocarcinoma of the lung. Clin Lung Cancer 2010, 11:E1-E4.

24. Shiao TH, Chang YL, Yu CJ, Chang YC, Hsu YC, Chang SH, Shih JY, Yang PC: Epidermal growth factor receptor mutations in small cell lung cancer: a brief report. J Thorac Oncol 2011, 6:195-198.

25. Sequist LV, Waltman BA, Dias-Santagata D, Digumarthy $S$, Turke AB, Fidias $P$, Bergethon K, Shaw AT, Gettinger S, Cosper AK, Akhavanfard S, Heist RS, Temel J, Christensen JG, Wain JC, Lynch TJ, Vernovsky K, Mark EJ, Lanuti M, lafrate AJ, Mino-Kenudson M, Engelman JA: Genotypic and histological evolution of lung cancers acquiring resistance to EGFR inhibitors. Sci Transl Med 2011, 3:75ra26.
26. Lu HY, Sun WY, Chen B, Zhang YP, Cai JF, Su D, Wang Z, Zheng YQ, Ma SL: Epidermal growth factor receptor mutations in small cell lung cancer patients who received surgical resection in China. Neoplasma 2012, 59:100-104.

27. Lu HY, Mao WM, Cheng QY, Chen B, Cai JF, Wang XJ, Wang Z, Xie FJ: Mutation status of epidermal growth factor receptor and clinical features of patients with combined small cell lung cancer who received surgical treatment. Oncol Lett 2012, 3:1288-1292.

28. Iyoda A, Travis WD, Sarkaria IS, Jiang SX, Amano H, Sato Y, Saegusa M, Rusch W, Satoh Y: Expression profiling and identification of potential molecular targets for therapy in pulmonary large-cell neuroendocrine carcinoma. Exp Ther Med 2011, 2:1041-1045.

29. De Pas TM, Giovannini M, Manzotti M, Trifirò G, Toffalorio F, Catania C, Spaggiari L, Labianca R, Barberis M: Large-cell neuroendocrine carcinoma of the lung harboring EGFR mutation and responding to gefitinib. J Clin Oncol 2011, 29:e819-e822.

30. Yanagisawa S, Morikawa N, Kimura Y, Nagano Y, Murakami K, Tabata T: Large-cell neuroendocrine carcinoma with EGFR mutation: possible transformation of lung adenocarcinoma. Respirology 2012, 17:1275-1277.

31. Balak MN, Gong Y, Riely GJ, Somwar R, Li AR, Zakowski MF, Chiang A, Yang G, Ouerfelli O, Kris MG, Ladanyi M, Miller VA, Pao W: Novel D761Y and common secondary T790M mutations in epidermal growth factor receptor-mutant lung adenocarcinomas with acquired resistance to kinase inhibitors. Clin Cancer Res 2006, 12:6494-6501.

32. Bean J, Riely GJ, Balak M, Marks JL, Ladanyi M, Miller VA, Pao W: Acquired resistance to epidermal growth factor receptor kinase inhibitors associated with a novel T854A mutation in a patient with EGFR-mutant lung adenocarcinoma. Clin Cancer Res 2008, 14:7519-7525.

33. Yu J, Kane S, Wu J, Benedettini E, Li D, Reeves C, Innocenti G, Wetzel R, Crosby K, Becker A, Ferrante M, Cheung WC, Hong X, Chirieac LR, Sholl LM, Haack H, Smith BL, Polakiewicz RD, Tan Y, Gu TL, Loda M, Zhou X, Comb MJ: Mutation-specific antibodies for the detection of EGFR mutations in non-small-cell lung cancer. Clin Cancer Res 2009, 15:3023-3028.

34. Brevet M, Arcila M, Ladanyi M: Assessment of EGFR mutation status in lung adenocarcinoma by immunohistochemistry using antibodies specific to the two major forms of mutant EGFR. J Mol Diagn 2010, 12:169-176.

doi:10.1186/2049-6958-8-47

Cite this article as: Sakai et al.: Large-cell neuroendocrine carcinoma of lung with epidermal growth factor receptor (EGFR) gene mutation and co-expression of adenocarcinoma markers: a case report and review of the literature. Multidisciplinary Respiratory Medicine 2013 8:47.

\section{Submit your next manuscript to BioMed Central and take full advantage of:}

- Convenient online submission

- Thorough peer review

- No space constraints or color figure charges

- Immediate publication on acceptance

- Inclusion in PubMed, CAS, Scopus and Google Scholar

- Research which is freely available for redistribution 